\title{
Research on Basic Database for Real Property Unified Registration
}

\author{
Guang Yang ${ }^{1}$, Zhihan Yang ${ }^{2}$, and Zhijie $\operatorname{Han}^{1}$ \\ ${ }^{1}$ College of Surveying and Geo-Informatics, Tongji University, Shanghai, China \\ ${ }^{2}$ School of Economics and Management, Tongji University, Shanghai, China
}

\begin{abstract}
This paper researches Shanghai's real property registration, studying the data integration of the information database of real property unified registration in Shanghai and the establishment of information systems of real property unified registration. The means of data cleaning and data integration are used to consolidate all kinds of basic data for real property which are in complex structure and different formats, building a basic information database for real property and providing a strong support for the establishment of information platform.
\end{abstract}

\section{Introduction}

In November 2013, the $31^{\text {st }}$ executive meeting of the State Council declared that the Ministry of Land and Resources was responsible for the guidance and supervision of the unified registration for real property throughout the country, including land, houses, grassland, woodland, sea area and so on, in order to achieve the "Four Unification" of registration organizations, registration books, registration basis and information platform. Subsequently, the SCOPSR (State Commission Office of Public Sectors Reform) issued "The Notice on the Duties of Integrating the Real Property Registration" to define its specific requirements. [1]

The Ministry of Land and Resources believes that the informatization level of Shanghai is high and its practical experience is rich, as it is the first to implement the registration of houses together with land in the country. It hopes that Shanghai will set an example and take the lead on the informatization of the real property unified registration, so that it authorizes the Information Center of the Resource of House and Land of Shanghai to undertake this nationwide work of "The Standard of Information Database for Real Property Registration" and "The Framework Plan for Real Property Unified Registration". Heilongjiang Province and other districts also decide to study and copy the informatization mode of Shanghai's real property unified registration. To build the basic platform of information management of real property registration is a significant support for both the implementation of the requirement from The State Council about the "Four Unification" of registration organizations, registration books, registration basis and information platform, and the promotion of accelerating the implementation of the real property unified registration regulation.

Information platform is the key component of the
"Four Unification", and it is also an important technological support for its implementation. With the realistic requirements of easing the masses' burden, ensuring transaction safety and sounding social credit system, information platform mainly aims at providing the legal and convenient service of information sharing and enquiry, on the premise of ensuring the information of real property is registered completely, accurately and timely. As a result, it is necessary to build up a unified database for real property registration to ensure that the information is complete, accurate as well as timely, through updating the data related to the registration on the receptionist in real time.

The beginning to build the unified database of real property registration is that there is a great deal of registration data of land, houses, woodland, grassland and sea areas in each department of each level in government institutions over the years under the decentralized registration system. Due to the differences among the databases of houses, woodland and grassland and the distinction of their data quality, it is tough to integrate and consolidate those data. In the course of setting up the information database, the data at the municipal level is the real origin of the data, which is the emphasis for the consolidation, coding and variation mechanism of the registration data of real property.

Against the backdrop mentioned above, it is of great practical significance to study how to use proper techniques and methods to build the information database of real property unified registration, so as to develop the information platform for real property unified registration, ensuring that the relevant departments implement the unified registration accurately and efficiently. 


\section{The Current Situation of Real Property Unified Registration and the Overview of Basic Data}

\subsection{The Current Situation of Real Property Unified Registration}

At present, as the real property registration is decentralized in different departments, there are a number of problems, such as the business rules is not unified or the data construct is not unified, etc. The status of domestic real property registration has following characteristics.

\subsubsection{The Registration is not Unified}

Currently, the work of real property registration is dispersed at different departments. The usage rights of the construction land and collective land ownership are registered in the land department, while the house ownership and other rights of houses are registered in the house and rural-urban building departments. In terms of the rural land contractual management right, grassland ownership or usage rights, they are registered in agriculture sector, while the ownership and right to use forest land are registered by the forestry department. In addition, the registration of the use of surface and intertidal zone are in the fishery sector, and the right to use sea is in the maritime sector. [2] These problems are mainly because the registration organizations and relevant laws are not unified.

\subsubsection{The Business Rules is not Unified}

The ministry of land and resources, the ministry of housing and urban-rural development, the forestry administration, ministry of agriculture and other departments have their respective laws as basis. [3] The forestry administration has the Forestry Law as a support for forest land registration. Grassland registration is carried out by the ministry of agriculture, which is based on the Grassland Law. While there is the Contracting of Rural Land Law for the registration of the rural land contract, with respect to house registration, there is the Urban Real Estate Administration Law for the ministry of housing and urban-rural development to carry out. Similarly, the fisheries sector has the Fisheries Law for the registration of the use right of surface and intertidal zone for aquaculture, and maritime department has the Management Law for the Usage of Sea Area for the registration of the intertidal zone of the sea area. Besides, the industry and commerce department implement the Guaranty Law for the mortgage of real property. As for the ministry of land and resources, the Law of Land Administration is undertook for the registration for land, in the Article 11th Section $3^{\text {rd }}$ of which it is also clearly defined that certifications of ownership or the usage rights of the woodland and grassland, as well as the usage right of the surface and intertidal zone for aquaculture should be respectively in accordance with the relevant provisions of the Forest Law of the People's Republic of China, the
Grassland Law of the People's Republic of China and the Fishery Law of the People's Republic of China, which shows the status quo of dispersed registration of land. [4]

\subsubsection{The Data Model is not Unified}

In the business about the registration of real property in each department, most of them have the concept on registration books or record cards. However, the meaning of this concept has so many differences in details that the interrelation of these elements cannot be described in a unified manner, especially in the deal with real property, rights, oblige and the registration process. Namely, they do not have the unified model of the data.

\subsection{The Overview of Basic Data}

The registration of the real property, involving the current land, houses, grassland, woodland, sea area and contractual right of rural land, etc., are in the charge of different sectors. [5] Therefore, the standard of the data and the business process are different, administrated on the basis of respectively independent system. Accordingly, to set up a unified basic platform of the information management for real property registration requires the design to be based on data consolidation, business process, and information system. With land as the core of the unified registration system of real property, its central idea is that the registrations of various use rights must rely on the corresponding registrations of land ownership, and the registration of the attached objects on the land shall depend on the registration of land use rights, while the subsequent registration should correspond to the early registration. [6]

The basic database of the registration information of real property is integrated and built by teasing and standardizing the current registration information of the real property that is in scattered storage with different format and different medium, according to the Database Standard of the Registration Information of Real Property, which lays a solid foundation for supporting the operation of the unified registration platform of real property. The principal sources of basic data are shown as follows.

Firstly, daily registration business. All of the implementation and its results as well as the process information of the real property registration will be brought into the database as the new source for the data. Secondly, deposit data of the real property registration. A large quantity of deposit data from previous registration under the dispersed-registration system, which is about the registration of land, houses, woodland, grassland and sea area, would be integrated to set up the interrelation on the basis of the unified database standard. In other words, apartments must be attached with the ownership information and buildings with the land information, all of which should be put into the database of real property registration. Thirdly, data of the results of cadastral rights survey. The results of boundary survey and ownership survey would be incorporated into the database as the basis of real property registration, through sorting out the integrated and consolidated data. 


\section{Data Consolidation Roadmap}

\subsection{Data Consolidation Objects}

The scope of the consolidation of information about real property registration includes the registration books and the historical registration files as well as the space information, including the information of land ownership, the usage right of construction land, the usage right of homestead, real estate rights, contractual rights of land, the use right of farmland, forestry rights, the use right of sea area and non-resident island, as well as the building ownership and water entitlement. The objects of data consolidation are stored through three kinds of medium. Firstly, it is electronic registration information. The original information of the real property registration has been completed by means of informatization. The existent and more intact data has set up electronic registration information database, which has formed the electronic registration books and electronic examination and approval archives. Secondly, it is electronic record. The registration archives database has been built for the original registration process and registration results, according to the relevant requirements of records management, and the file index has been established. Thirdly, it is the paper files. The process and results of registration are still stored in traditional paper-based way.

\subsection{Data Consolidation Process}

\subsubsection{Preparation}

First of all, do the status quo survey about current registration information of real property well, collect the data standard of original registration, compare and analyze them with the Database Standard of the Registration Information of Real Property. After extracting a certain amount of data for the plot test, draw up the mapping relation chart of data and thus to formulate the detailed execution plans and technical instructions. [7]

\subsubsection{Data Standardization}

Then, according to the implementation plans and technical instructions, the original registration information would be standardized based on the data description of the Real Property Registration Information Database. This step mainly contains the following aspects. First of all, it is the specification for semantic consistency, which is designed to solve problems about the same name with heterogeneous medium and the same medium with different names. Then, it is the data type matching, dealing with problems about non-uniform data types, decimal numerical digit and quantity units. Further, it is unified coordinate system, settling the problem that coordinate reference is inconsistent in a specific geographical area. Finally, it should be the information complement. The incomplete core registration information needs to be replenished in order to ensure the data completeness.

\subsubsection{Reconstruction of Data Logical Relationship}

Moreover, basing on the requirements of information correlation of real property register, standardized registration information ought to be used to establish electronic registration information book respectively about the land ownership, use right of construction land, use right of homestead land, real estate right, contractual right of land, use right of farmland, forestry right, use right of the sea area and non-resident island, ownership of construction and water-drawing right and so on. Besides, the related information of unified registration objects should be linked together, associated with the registration process and registration file.

\subsubsection{Locating Registration Information in Relevant Land}

In addition, it is necessary to locate the registration information with complete logical relationship in relevant land, including the land ownership, use right of construction land, use right of homestead land, real estate right, contractual right of land, use right of farmland, forestry right, use right of the sea area and non-resident island, ownership of construction and water-drawing right and so on, so as to code each plot of land and record it, and code the real property unit according to the code rules of real property units.

\subsubsection{Data Storage}

The final step is to store the data that has been settled according to the above steps, in accordance with the Database Standard of the Registration Information of Real Property. Both spatial information and non-spatial information should achieve their data collection as required.

\subsection{Data Consolidation Flow Path}

Database consolidation preparation: The flow chart of preparation is shown in the Figure 1.

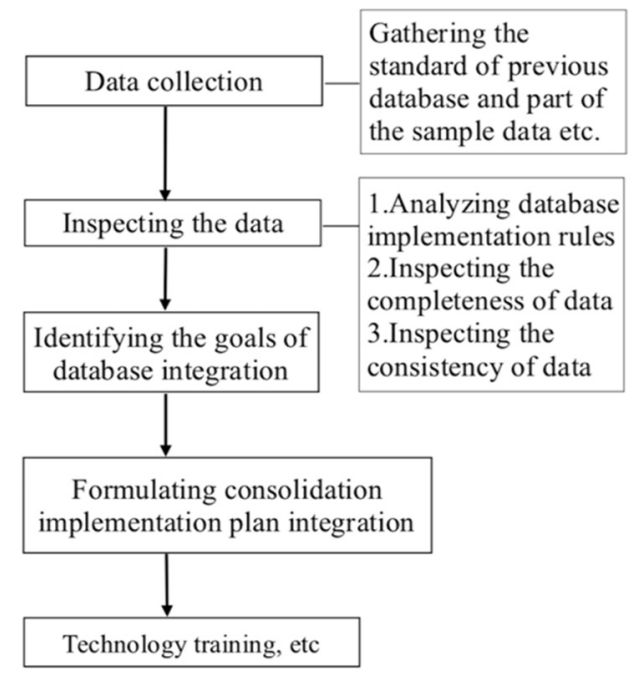

Fig.1. The flow chart of database consolidation preparation 
Data standardization: (the land ownership, use right of construction land, use right of homestead land, real estate right, contractual right of land, use right of farmland, forestry right, use right of the sea area and non-resident island, ownership of construction and water-drawing right, etc.) (1) Semantic consistency standardization, (2) Data type standardization, (3) Coordinate reference consistency, (4) Information complement.

Reconstruction of logical relationship: The registration information about the land ownership, use right of construction land, use right of homestead land, real estate right, contractual right of land, use right of farmland, forestry right, use right of the sea area and non-resident island, ownership of construction and water-drawing right ought to build up the logical relationship, taking the registration object as unit, in order to form the relevant electronic register.

Locating the registration information to the relevant land: The electronic register of the land ownership, use right of construction land, use right of homestead land, real estate right, contractual right of land, use right of farmland, forestry right, use right of the sea area and nonresident island, ownership of construction and waterdrawing right should be located to the land in the form of real property registers. They are coded according to the coding regulation of land and real property units, so as to form real property registers. [8]

Storing data: In accordance with the Database Standard of the Registration Information of Real Property, store the data that contains the information of the land ownership, use right of construction land, use right of homestead land, real estate right, contractual right of land, use right of farmland, forestry right, use right of the sea area and non-resident island, ownership of construction and water-drawing right.

\section{Conclusions}

All in all, real property unified registration involves several aspects including institutional policies, institutional personnel, laws and regulations, technical standard and so on, with limited time, tough tasks, widespread influence and wide-covered range. Certainly, data is the blood of the system and is the premise condition for all tasks. Setting up the basic database of real property unified registration is the preliminary work for real property unified registration, to which the preparation of basic data is especially significant. There is no doubt that the basic database of unified registration information of real property provides the data support for the whole real property unified registration, and is also the key to support the information platform. Meanwhile it is the backbone for carrying out the registration business of real property, and is essential in the whole real property unified registration.

\section{References}

1. L H. Wang, Z H. Sun, Y. Peng, et al., The Study of Building the Basic Platform of the Data Consolidation and Management of Real Property Registration Information, Geomatics World, 4, 76-82, (2014)

2. C H. Yan, The Research on the Current Situation on the Purpose of Building the Real Property Registration System, Legal system and economy, 9, (2014)

3. Z Y. Tong, The Research on the Registration System for Real Property, Shandong University, (2013)

4. Z C. Li, The Study of Real Property Unification Registration, East China University of Political Science and Law, (2011)

5. National People's Congress, Property Law of the People's Republic of China, People's Publishing House, (2007)

6. M Z. Wang, The Research on the Building of the Registration System of Real Property In China, Truth Seeking, S1, 95-96, (2012)

7. Z M. Zhang, H Y. Xu, Research on Key Technologies of Data Integration Construction for the Land Registration of Real Property and Real Estate Data, Modern Mapping, 39(4), 56-58, (2016)

8. X. Cheng, The Research on the Unit of Real Property Registration, Real estate in China, 3, 27-28, (2011) 